\title{
An Analysis of Range Conservation
}

\section{Academic Training}

\section{WAYNE COOK AND CHARLES D. BONHAM}

Highlight: $A$ survey of range professionals employed by federal agencies was found to be an effective means for determining educational needs of range managers. Eighteen western universities produce essentially all Range Conservationists employed by federal agencies and two of these universities combined produce more than one-third of these professionals. Only 57.5\% of the Range Conservationists in 1969 had BS degrees in range science, while 42.5\% received sufficient course credits in range to qualify them for Civil Service appointments. Most Range Conservationists believed that ecology was the most important basic subject matter, while range management courses were most important for training as Range Conservationists. Respondents indicated that experience was helpful but not as essential as proper academic training.

In $1969,1,605$ questionnaires ${ }^{1}$ were sent to range conservation

\footnotetext{
Authors are head and associate professor, Department of Range Science, Colorado State University, Fort Collins.

I Williams, R. E. 1970. Range conservationist need for education: Rangeland action agency's views. Paper presented at the 1970 Annual Meeting, Society for Range Management, Denver, Colorado, February 12, 1970.
}

employees who were currently employed by the Forest Service (FS), the Bureau of Land Management (BLM), or the Soil Conservation Service (SCS). The survey was taken from employees qualified by these agencies under the Range Conservationists or Range Examiner Civil Service Series. These employees qualified for range positions by either receiving a $\mathrm{BS}$ degree in range science or range management, or by having the minimum course credits in range. This minimum number of credits has varied from as low as 6 semester credits to as much as 12 semester credits during the past few years.

The present Civil Service Occupational Series under which these range conservationists have served include: 401-General Biological Series (Ecologist); 454-Range Conservationist; 457-Soil Scientist; 460-Professional Forester; and 486-Professional Wildlife Biologist.

The results of this survey should be useful to university personnel involved in range education, as well as to land management agencies, for determining educational needs in range management and perhaps in natural resource management in general. 


\section{Universities and Range Degrees}

The data in Table 1 shows the number of individuals graduating from 18 colleges or universities that offered major coursework in range science or range management prior to 1967 . Students from these schools could also meet Civil Service standards without obtaining a degree in range science or range management. Thus, students with and without degrees in range science qualified under the Civil Service Series as Range Conservationists and were employed by the SCS, the BLM, and the FS. The data show that two universities (Utah State University and Colorado State University) produced almost $43 \%$ of the Range Conservationists who held BS degrees in range science and about $29 \%$ of the Range Conservationists who did not have degrees in range science. It is of interest to note that only $57.5 \%$ of these employees received BS degrees in range, while $42.5 \%$ received enough course credits in range to qualify for Civil Service appointments as Range Conservationists. The data listed in Table 1 include only 1,409 of the total of 1,605 respondents because 196 did not list a degree major.

Federal land agency administrators were among those polled, and $26 \%$ of these felt that a range degree qualified individuals to handle assignments that dealt with resource and environmental problems other than those traditional in range management. Additionally, $71 \%$ of these administrators indicated that a formal degree in range was not necessarily a major factor which qualified individuals to solve these problems. The remaining three percent said that a range degree did not qualify individuals in any way to deal with these nontraditional problems.

\section{Membership in Professional Societies}

As might be expected, the majority of these employees were members of the Society for Range Management (SRM) (Table 2). However, only $69.5 \%$ of those persons who had BS degrees in range science were members of the SRM, while only $58 \%$ of the Range Conservationists who did not have a range degree were members. Approximately $50 \%$ of the BLM Range Conservationists were members of the SRM, whereas the SCS and FS had 72 and $67 \%$ of their Range Conservationists as members of SRM, respectively (Table 2). Range Conservationists who had met the requirements by coursework other than a BS degree in range had a higher percentage of membership in other professional Societies such as the Soil Conservation Society, Society of American Foresters, Wildlife Society and others (Table 2).

\section{Subject Matter Training}

Information presented in Tables 3 and 4 indicated that ecology and range management courses were given as the most beneficial in the Range Conservationist's training. These courses were also suggested as the most important in updating a Range Conservationist for the responsibilities he is expected to meet in his position. Ecology was listed as the most important basic subject matter received in their range training with basic range management courses listed second in importance (Table 3). A greater percentage of the more recent graduates responded that they needed more range management, which is in contrast to a greater percentage of the earlier graduates who said that more ecology was needed in the range curriculum. This could have resulted from fewer ecology courses being available to earlier graduates. However, all respondents, regardless of when they graduated, indicated that basic ecology was the most important discipline required in their training (Table 3). More training was suggested in plant physiology and botanical sciences by respondents who had more than 4 years of service.

There were several interesting contrasts among personnel in the various federal land management

Table 1. Universities attended for BS degrees in range science or where training in range management was sufficient to qualify the employee for a Range Conservationist or Range Examiner position. Data are presented in actual numbers except in last two columns.

\begin{tabular}{|c|c|c|c|c|c|c|c|c|c|c|}
\hline \multirow[b]{3}{*}{ Schools } & \multirow{2}{*}{\multicolumn{2}{|c|}{ SCS }} & \multirow{2}{*}{\multicolumn{2}{|c|}{ BLM }} & \multirow{2}{*}{\multicolumn{2}{|c|}{ FS }} & \multicolumn{4}{|c|}{ Combined } \\
\hline & & & & & & & \multicolumn{2}{|c|}{ Numbers } & \multicolumn{2}{|c|}{ Percent } \\
\hline & $\begin{array}{c}\text { Range } \\
\text { sci. } \\
\text { degree }\end{array}$ & $\begin{array}{c}\text { Non- } \\
\text { range } \\
\text { degree }\end{array}$ & $\begin{array}{c}\text { Range } \\
\text { sci. } \\
\text { degree }\end{array}$ & $\begin{array}{c}\text { Non- } \\
\text { range } \\
\text { degree }\end{array}$ & $\begin{array}{c}\text { Range } \\
\text { sci. } \\
\text { degree }\end{array}$ & $\begin{array}{c}\text { Non- } \\
\text { range } \\
\text { degree }\end{array}$ & $\begin{array}{c}\text { Range } \\
\text { sci. } \\
\text { degree }\end{array}$ & $\begin{array}{c}\text { Non- } \\
\text { range } \\
\text { degree }\end{array}$ & $\begin{array}{c}\text { Range } \\
\text { sci. } \\
\text { degree }\end{array}$ & $\begin{array}{c}\text { Non- } \\
\text { range } \\
\text { degree }\end{array}$ \\
\hline Ariz., Univ. of & 8 & 3 & 5 & 9 & 8 & 3 & 21 & 15 & 2.6 & 2.5 \\
\hline Calif., Univ. of & 3 & 1 & 3 & 2 & 3 & 2 & 9 & 5 & 1.1 & $*$ \\
\hline Colo. State & 19 & 21 & 9 & 17 & 78 & 50 & 106 & 88 & 13.1 & 14.7 \\
\hline Fort Hays Ks. State & 1 & 16 & 1 & 12 & 0 & 1 & 2 & 29 & $*$ & 4.8 \\
\hline Idaho, Univ. of & 21 & 3 & 25 & 12 & 25 & 21 & $7 \overline{1}$ & 36 & 8.8 & 6.0 \\
\hline Montana State & 11 & 5 & 15 & 14 & 5 & 8 & 31 & 27 & 3.8 & 4.5 \\
\hline Montana, Univ. of & 21 & 5 & 11 & 14 & 37 & 23 & 69 & 42 & 8.5 & 7.0 \\
\hline Nevada, Univ. of & 0 & 0 & 1 & 5 & 1 & 0 & 2 & 5 & $*$ & $*$ \\
\hline N. Mex. State & 12 & 4 & 17 & 6 & 21 & 5 & 50 & 15 & 6.2 & 2.5 \\
\hline N. Dak. State & 0 & 4 & 0 & 4 & 0 & 0 & 0 & 8 & $*$ & 1.4 \\
\hline Oregon State & 3 & 4 & 5 & 3 & 3 & 5 & 11 & 12 & 1.4 & 2.0 \\
\hline S. Dak. State & 2 & 3 & 4 & 0 & 2 & 0 & 8 & 3 & 1.0 & $*$ \\
\hline Sul Ross & 5 & 9 & 1 & 2 & 0 & 0 & 6 & 11 & $*$ & 1.9 \\
\hline Texas A\&M & 38 & 12 & 5 & 1 & 9 & 1 & 52 & 14 & 6.4 & 2.4 \\
\hline Texas Tech & 11 & 8 & 4 & 2 & 3 & 1 & 18 & 11 & 2.2 & 1.9 \\
\hline Utah State & 29 & 8 & 89 & 10 & 124 & 65 & 242 & 83 & 29.8 & 13.9 \\
\hline Washington State & 1 & 7 & 7 & 2 & 9 & 7 & 17 & 16 & 2.1 & 2.7 \\
\hline Wyoming, Univ. of & 5 & 2 & 16 & 14 & 11 & 9 & 32 & 25 & 3.9 & 4.2 \\
\hline Other universities & 39 & 47 & 13 & 35 & 12 & 61 & 64 & 153 & 7.9 & 25.6 \\
\hline Total & 229 & 162 & 231 & 174 & 351 & 262 & 811 & 598 & 100.0 & 100.0 \\
\hline
\end{tabular}

${ }^{*}$ Less than one percent $(1 \%)$. 
agencies as to what was important in a range management curriculum for a BS degree. The range degree and non-range degree specialists employed by SCS and FS expressed a common view that basic ecology was the most important discipline. The range degree employees of BLM likewise thought that ecology was decidedly most important, but non-range science degree employees of BLM working as Range Conservationists thought that range management was more important than ecology.

There was little or no difference in responses from persons holding range degrees and other degree specialists when averaged over all land management agencies as to importance of the six basic subject matter areas (Table 3). However, the average percent of respondents within each agency listing the six disciplines indicated that a marked difference existed among the three agencies. The BLM and SCS respondents indicated that 70 and $80 \%$, respectively, thought that the six disciplines were important regardless of the degree that the Range Conservationist held. These are in contrast to the $56 \%$ of the FS Range Conservationists who felt that these subjects were the most important. The remaining percentages indicated that other courses were as important or more important than those included in the six disciplines listed in Table 3.

Courses or subject matter areas considered to be highly important in carrying out the assignments of a Range Conservationist, regardless of their employing federal agency, were: first, range management; second, ecology; and third, plant taxonomy (Table 4).

The non-range degree range employee thought that plant taxonomy should have been required in his formal education. Apparently, field experience made up for a great many of his educational deficiencies, but plant taxonomy, plant ecology, and grazing management appeared to remain a void (Table 4).

The trends expressed in Table 4 suggested that range specialists with other degrees had different deficiences than specialists with range degrees. These deficiencies could have been the result of differences in academic training and job assignments. In any case, these data suggested that several years of experience were gained before the
Table 2. Range Conservationists' membership in professional societies. Data expressed as a percent of 1,605 respondents.

\begin{tabular}{|c|c|c|c|c|c|c|c|c|}
\hline \multirow[b]{2}{*}{ Societies } & \multicolumn{2}{|c|}{ SCS } & \multicolumn{2}{|c|}{ BLM } & \multicolumn{2}{|c|}{ FS } & \multicolumn{2}{|c|}{ Combined } \\
\hline & $\begin{array}{l}\text { Range } \\
\text { science } \\
\text { degree }\end{array}$ & $\begin{array}{c}\text { Non- } \\
\text { range } \\
\text { degree } \\
\end{array}$ & $\begin{array}{l}\text { Range } \\
\text { science } \\
\text { degree }\end{array}$ & $\begin{array}{c}\text { Non- } \\
\text { range } \\
\text { degree }\end{array}$ & $\begin{array}{l}\text { Range } \\
\text { science } \\
\text { degree }\end{array}$ & $\begin{array}{c}\text { Non- } \\
\text { range } \\
\text { degree }\end{array}$ & $\begin{array}{l}\text { Range } \\
\text { science } \\
\text { degree }\end{array}$ & $\begin{array}{r}\text { Non- } \\
\text { range } \\
\text { degree }\end{array}$ \\
\hline $\begin{array}{l}\text { Soc. for } \\
\text { Range Manage. }\end{array}$ & 77.3 & 67.3 & 50.6 & 49.4 & 76.9 & 58.0 & 69.5 & 58.0 \\
\hline $\begin{array}{l}\text { Soc. of Amer. } \\
\text { Forest. }\end{array}$ & $*$ & 3.1 & 2.2 & 5.2 & 17.9 & 40.5 & 8.5 & 20.1 \\
\hline $\begin{array}{l}\text { Soil Conserv. } \\
\text { Soc. }\end{array}$ & 56.3 & 67.9 & 3.9 & 1.1 & 2.0 & 2.7 & 17.9 & 19.9 \\
\hline $\begin{array}{l}\text { Amer. Soc. } \\
\text { of Agron. } \\
\text { Ecol. Soc. }\end{array}$ & - & 1.9 & $*$ & $*$ & - & - & $*$ & $*$ \\
\hline $\begin{array}{l}\text { of Amer. } \\
\text { Wildlife }\end{array}$ & 2.6 & 2.5 & $*$ & - & - & 1.5 & $*$ & 1.3 \\
\hline $\begin{array}{l}\text { Soc. } \\
\text { Amer. Inst. }\end{array}$ & 1.3 & 2.5 & 5.2 & 13.2 & 8.3 & 16.4 & 5.4 & 11.7 \\
\hline Biol. Sci. & 1.7 & 1.2 & $*$ & * & $*$ & 2.7 & $*$ & 1.7 \\
\hline $\begin{array}{l}\text { Amer. Forest. } \\
\text { Ass. }\end{array}$ & - & - & $*$ & 1.1 & 2.6 & 4.2 & 1.4 & 2.1 \\
\hline
\end{tabular}

*Less than one percent $(1 \%)$.

Table 3. The six courses or subject matter areas listed as most important in the range management curriculum. Data expressed as a percent of respondents stratified by years of service in the agencies.

\begin{tabular}{|c|c|c|c|c|c|c|c|c|}
\hline \multirow[b]{3}{*}{ Courses } & \multicolumn{8}{|c|}{ Years of service } \\
\hline & \multicolumn{2}{|c|}{$1-4$} & \multicolumn{2}{|c|}{$5-8$} & \multicolumn{2}{|c|}{$9-12$} & \multicolumn{2}{|c|}{ Combined } \\
\hline & $\begin{array}{l}\text { Range } \\
\text { science } \\
\text { degree }\end{array}$ & $\begin{array}{c}\text { Non- } \\
\text { range } \\
\text { degree }\end{array}$ & $\begin{array}{l}\text { Range } \\
\text { science } \\
\text { degree }\end{array}$ & $\begin{array}{c}\text { Non- } \\
\text { range } \\
\text { degree }\end{array}$ & $\begin{array}{c}\text { Range } \\
\text { science } \\
\text { degree }\end{array}$ & $\begin{array}{c}\text { Non- } \\
\text { range } \\
\text { degree }\end{array}$ & $\begin{array}{l}\text { Range } \\
\text { science } \\
\text { degree }\end{array}$ & $\begin{array}{l}\text { Non- } \\
\text { range } \\
\text { degree }\end{array}$ \\
\hline Ecology & 23.1 & 17.3 & 22.6 & 23.6 & 27.7 & 30.5 & 24.6 & 24.2 \\
\hline Range manage. & 18.8 & 17.3 & 12.3 & 11.5 & 9.7 & 8.4 & 13.5 & 12.1 \\
\hline Plant taxonomy & у 11.5 & 18.2 & 9.4 & 12.2 & 9.0 & 9.9 & 10.0 & 13.1 \\
\hline \multicolumn{9}{|c|}{ Plant physiol- } \\
\hline ogy and botany & 12.1 & 9.0 & 17.0 & 17.5 & 15.4 & 10.7 & 15.0 & 12.9 \\
\hline Soils & 3.6 & 4.5 & 3.3 & 2.7 & 2.6 & 1.5 & 3.2 & 2.8 \\
\hline Agrostology & 3.6 & $*$ & 3.3 & 2.0 & 1.9 & $*$ & 3.0 & 1.3 \\
\hline
\end{tabular}

${ }^{*}$ Less than one percent $(1 \%)$.

Table 4. Shortcourses listed as being most useful in carrying out Range Conservationist assignments. Data expressed as a percent of all respondents.

\begin{tabular}{|c|c|c|c|c|c|c|c|c|}
\hline \multirow[b]{3}{*}{ Subject area } & \multicolumn{8}{|c|}{ Years of service } \\
\hline & \multicolumn{2}{|c|}{$1-4$} & \multicolumn{2}{|c|}{$5-8$} & \multicolumn{2}{|c|}{$9-12$} & \multicolumn{2}{|c|}{ Combined } \\
\hline & $\begin{array}{r}\text { Range } \\
\text { science } \\
\text { degree }\end{array}$ & $\begin{array}{l}\text { Non- } \\
\text { range } \\
\text { degree }\end{array}$ & $\begin{array}{l}\text { Range } \\
\text { science } \\
\text { degree }\end{array}$ & $\begin{array}{c}\text { Non- } \\
\text { range } \\
\text { degree }\end{array}$ & $\begin{array}{l}\text { Range } \\
\text { scicnce } \\
\text { degree }\end{array}$ & $\begin{array}{c}\text { Non- } \\
\text { range } \\
\text { degree }\end{array}$ & $\begin{array}{l}\text { Range } \\
\text { science } \\
\text { degree }\end{array}$ & $\begin{array}{r}\text { Non- } \\
\text { range } \\
\text { degree } \\
\end{array}$ \\
\hline Range manage. & 16.4 & 9.1 & 13.2 & 12.8 & 14.4 & 13.8 & 14.3 & 12.1 \\
\hline Ecology & 6.6 & 4.5 & 6.6 & 9.5 & 10.3 & 8.4 & 7.7 & 8.0 \\
\hline Plant taxonomy & 4.8 & 7.3 & 3.3 & 4.7 & 5.2 & 6.1 & 4.3 & 5.9 \\
\hline $\begin{array}{l}\text { Range eco- } \\
\text { nomics }\end{array}$ & 4.2 & 2.7 & 2.4 & 5.4 & 4.5 & 3.8 & 3.6 & 4.1 \\
\hline $\begin{array}{l}\text { Watershed } \\
\text { manage. }\end{array}$ & 4.8 & 5.5 & 1.9 & 1.4 & 3.2 & 2.3 & 3.2 & 2.8 \\
\hline $\begin{array}{l}\text { Wildlife manage. } \\
\text { Recreation }\end{array}$ & 3.0 & 4.5 & 4.7 & 3.4 & $*$ & - & 3.0 & 2.6 \\
\hline $\begin{array}{l}\text { manage } \\
\text { Economics }\end{array}$ & 1.2 & 1.8 & 2.8 & $*$ & 3.2 & $*$ & 2.4 & 1.0 \\
\hline and adm. & 1.8 & - & 2.8 & 2.0 & 3.2 & 1.5 & 2.6 & 1.3 \\
\hline English & 1.2 & 1.8 & $*$ & 2.7 & 4.5 & 1.5 & 2.1 & 2.1 \\
\hline $\begin{array}{l}\text { Soil and } \\
\text { water sci. }\end{array}$ & 6.1 & 4.5 & 4.2 & 6.1 & 5.2 & 8.4 & 5.1 & 6.4 \\
\hline Communications & is $*$ & - & - & 1.4 & - & $*$ & $*$ & $*$ \\
\hline
\end{tabular}

*Less than one percent $(1 \%)$. 
range employee realized the importance of some of the subject matter areas that are common to range management.

There were some differences in opinions among range employees within the three federal land management agencies as to a need for continuing education. There were also differences between those who had attained degrees in range and those who did not have range degrees with respect to continuing education in range management. The Range Conservationists of BLM and FS, regardless of the degree held, thought that specialized courses were absolutely essential to update Range Conservationists. SCS Range Conservationists holding a degree in range science thought that these kinds of courses were important but not essential; while SCS Range Conservationists without a range degree thought that such courses were essential. For example, short courses most frequently listed were: range management, ecology, watershed management, and wild life management in that order. In general, the majority of Range Conservationists said that specialized courses were essential in continuing their education. Contrary to present-day thinking, communication needs were not listed as being important by the respondents.

\section{Experience and Training}

Most respondents indicated that experience along with formal education was essential in qualifying them for fulfilling their assignments as Range Conservationists. According to this survey, more than $50 \%$ of the range specialists in the FS and the SCS believed that experience along with formal education made them highly qualified for their job. On the other hand, slightly more than $40 \%$ believed that experience along with education was only somewhat helpful for qualifying them. The remaining percentage was intermediate in this respect.

Only about one-third of the Range Conservationists in BLM thought that experience along with formal education highly qualified them for their positions, while two-thirds felt experience along with their education was only slightly beneficial. When averaged over all agencies, it was found

Table 5. Years of experience in federal agencies for employees originally employed as Range Conservationists with and without range science degrees. Data expressed as a percentage of respondents.

\begin{tabular}{|c|c|c|c|c|c|c|c|c|}
\hline \multirow[b]{2}{*}{$\begin{array}{c}\text { Years of } \\
\text { experience }\end{array}$} & \multicolumn{2}{|c|}{ SCS } & \multicolumn{2}{|c|}{ BLM } & \multicolumn{2}{|c|}{ FS } & \multicolumn{2}{|c|}{ Combined } \\
\hline & $\begin{array}{l}\text { Range } \\
\text { science } \\
\text { degree }\end{array}$ & $\begin{array}{l}\text { Non- } \\
\text { range } \\
\text { degree }\end{array}$ & $\begin{array}{r}\text { Range } \\
\text { science } \\
\text { degree }\end{array}$ & $\begin{array}{l}\text { Non- } \\
\text { range } \\
\text { degree }\end{array}$ & $\begin{array}{c}\text { Range } \\
\text { science } \\
\text { degree }\end{array}$ & $\begin{array}{l}\text { Non- } \\
\text { range } \\
\text { degree }\end{array}$ & $\begin{array}{l}\text { Range } \\
\text { science } \\
\text { degree }\end{array}$ & $\begin{array}{l}\text { Non- } \\
\text { range } \\
\text { degree }\end{array}$ \\
\hline 2 & 6.1 & 3.1 & 5.6 & 2.9 & 2.3 & 5.0 & 4.3 & 3.8 \\
\hline 3 & 9.6 & 5.6 & 6.9 & 8.0 & 6.6 & 3.4 & 7.5 & 5.4 \\
\hline 4 & 7.9 & 8.0 & 5.2 & 9.8 & 3.1 & 5.7 & 5.1 & 7.5 \\
\hline 5 & 5.2 & 5.6 & 3.9 & 5.2 & 7.4 & 5.0 & 5.8 & 5.2 \\
\hline 6 & 4.8 & 2.5 & 9.1 & 5.7 & 6.3 & 5.0 & 6.7 & 4.5 \\
\hline 7 & 3.9 & 1.2 & 9.1 & 12.6 & 7.7 & 6.1 & 7.0 & 6.7 \\
\hline 8 & 4.8 & 2.5 & 13.0 & 14.9 & 3.7 & 7.6 & 6.7 & 8.4 \\
\hline 9 & 1.3 & 3.7 & 5.6 & 5.7 & 6.6 & 5.3 & 4.8 & 5.0 \\
\hline 10 & 4.8 & 4.3 & 6.5 & 2.9 & 5.7 & 10.3 & 5.7 & 6.5 \\
\hline 11 & 2.6 & 4.9 & 5.2 & 4.0 & 6.3 & 5.3 & 4.9 & 4.8 \\
\hline
\end{tabular}

that considerably more individuals with a degree in range said that their experience along with their academic training was essential for carrying out their responsibilities than those without range degrees. This contrast was surprising, since it would appear that Range Conservationists without a range science degree would benefit markedly more from experience than the range degree specialist.

A majority of the respondents indicated that an advanced degree in range at either the $\mathrm{MS}$ or $\mathrm{PhD}$ level was not essential or even desirable as an aid in carrying out present assignments or possible future assignments. However, the majority of respondents did indicate that additional formal education or short courses would contribute substantially in assisting them in present and future assignments in rangeland environments.

Most respondents said that experience in several geographical regions was very helpful in preparing them for their present position, but only about one-fourth said it was essential. For the most part, all employees of each agency responded about the same way with respect to this kind of experience.

\section{Employment and Years of Experience with Agencies}

Most respondents suggested that experience with more than one land management agency was of only minor importance as an aid in their assignments now or assignments anticipated in the future.
As illustrated in Table 5, there were some years when all federal land management agencies employed more Range Conservationists than others. There were also years when one agency employed far more Range Conservationists than other agencies. Furthermore, it is interesting to note that during some years all agencies c mployed more Range Conservationists without BS degrees in range than with range degrees. In some years these federal agencies employed almost twice as many Range Conservationists without BS degrees in range science as the range degree specialists (Table 5).

\section{Conclusions}

Range professionals over the years have had difficulty in identifying their specific expertise and likewise the subject matter which is essential in training them for their job. This is partially a result of changing knowledge and problems, but may also be a result of inadequacy in the training which is necessary for managing the biological system through a holistic approach. This survey has shown that Range Conservationists feel that basic coursework should emphasize ecology, but general curriculum coursework should emphasize range management. These results indicated that basic ecology should be the foundation of academic training, while applied courses in range management are necessary building blocks to complete a well-rounded education to be employed as a rangeland manager. 